\title{
Keanekaragaman dan Pemanfaatan Tanaman Obat pada Pekarangan di Dumoga Utara, Kabupaten Bolaang Mongondow, Sulawesi Utara
}

\author{
(Diversity and Utilization of Medicinal Plants Home Yards \\ in North Dumoga, Bolaang Mongondow Regency, North Sulawesi) \\ Dewi Lestari, Roni Koneri, Pience Veralyn Maabuat \\ ${ }^{1)}$ Jurusan Biologi, FMIPA Universitas Sam Ratulangi, Manado 95115 \\ *Email korespondensi: $17101102033 @$ student.unsrat.ac.id
}

(Article History: Received January 12, 2021; Revised March 8, 2021; Accepted April 7, 2021)

\begin{abstract}
ABSTRAK
Tanaman obat merupakan tanaman yang memiliki komponen aktif dan diyakini oleh masyarakat dapat menyembuhkan penyakit. Penelitian ini bertujuan untuk menganalisis keanekaragaman dan pemanfaatan tanaman obat pada pekarangan di Dumoga Utara, Kabupaten Bolaang Mongondow, Sulawesi Utara. Metode pengambilan sampel menggunakan purposive sampling. Pemilihan responden dilakukan dengan metoda snowball sampling. Hasil penelitian didapatkkan sebanyak 25 famili, yang terdiri dari 46 spesies dan 2691 individu tanaman obat. Famili yang banyak ditemukan jumlah spesies dan individunya adalah Zingeberaceae, merupakan famili yang banyak ditemukan jumlah spesies dan individunya. Spesies yang memiliki kelimpahan tertinggi adalah Sauropus androgynus, kemudian Zingiber officinale dan Curcuma longa. Indek kekayaan, keanekaragaman dan kemerataan spesies tertinggi pada pekarangan Suku Jawa. Bentuk hidup tanaman obat yang paling banyak ditemukan adalah herba dan perdu. Daun merupakan bagian tanaman yang banyak dimanfaatkan untuk tanaman obat dan proses pengolahan umumnya dengan cara direbus. Pemanfaatan tanaman obat pekarangan oleh masyarakat dapat digunakan untuk mengobati 18 jenis penyakit.

Kata kunci: Tanaman obat; Zingiberaceae, Sauropus androgynus, herba.
\end{abstract}

ABSTRACT
Medicinal plants are plants that have active components and are believed by the community to cure diseases. This study aims to analyze the diversity and utilization of medicinal plants in the yard in North Dumoga, Bolaang Mongondow Regency, North Sulawesi. The sampling method used was purposive sampling. The selection of respondents was carried out using the snowball sampling method. The results of the study were 25 families, consisting of 46 species and 2691 individual medicinal plants. The family with the highest number of species and individuals was Zingeberaceae, which was the family with the highest number of species and individuals. The species with the highest abundance were Sauropus androgynus, then Zingiber officinale and Curcuma longa. The highest index of species richness, diversity and evenness was in the Javanese tribe. The most common forms of medicinal plant life are herbs and shrubs. Leaves are part of a plant that is widely used for medicinal plants and in general processing by boiling. The use of yard medicinal plants by the community can be used to treat 18 types of diseases.

Key words: Medicinal plants; Zingiberaceae, Sauropus androgynus, herb.

\section{PENDAHULUAN}

Tanaman obat merupakan tanaman yang bagian-bagiannya dapat dimanfaatkan. Bagian tanaman yang dapat dimanfaatkan diantaranya akar, batang, daun, buah maupun hasil ekskresinya diyakini dapat menyembuhkan atau mengurangi rasa sakit (Falah et al. 2013). Umumnya tanaman obat dapat diklasifikasikan menjadi tanaman obat tradisional dimana dipercayai masyarakat memiliki khasiat obat dan telah digunakan sebagai bahan baku pembuatan obat tradisional. Tanaman obat modern merupakan spesies tanaman obat yang telah dibuktikan secara ilmiah mengandung senyawa bioaktif yang berkhasiat obat dan dipertanggungjawabkan penggunaannya secara medis. Tanaman obat potensial 
mengandung senyawa atau bahan aktif yang berkhasiat obat (Rubiah et al. 2015).

Tanaman obat dapat ditemukan pada berbagai tipe habitat seperti hutan, lahan pertanian dan ditanam pada lahan pekarangan. Lahan pekarangan merupakan salah satu lahan yang berpotensi dimanfaatkan untuk menanam berbagai spesies tanaman seperti tanaman hias, buahbuahan, sayur-mayur, rempah-rempah, dan tanaman pangan lainnya. Lahan pekarangan juga dapat dijadikan lokasi budidaya tanaman obat keluarga (TOGA) seperti kunyit, jahe, temulawak, dan sereh (Oktaviani et al. 2020).

Pemanfaatan sumber daya alam yang berpotensi sebagai obat dapat bermula dari pekarangan rumah masyarakat di lingkungan tempat tinggal pedesaan (Larassati et al. 2019). Hal ini disebabkan karena masyarakat pedesaan masih menggunakan pengobatan tradisional dengan memanfaatkan tanaman pada pekarangannya. Manfaat obat tradisional yang dirasakan oleh masyarakat adalah kemudahan untuk memperolehnya dan bahan bakunya dapat ditanam di pekarangan sendiri, murah dan dapat diramu sendiri di rumah. Hampir setiap masyarakat pernah menggunakan tanaman obat untuk mengobati berbagai penyakit (Lubis et al. 2015).

Pemanfaatan pekarangan untuk tanaman obat oleh masyarakat bervariasi diantara suatu wilayah dengan wilayah lainnya. Perbedaan keanekaragaman dan pemanfaatan tanaman obat di pekarangan sangat dipengaruhi oleh tingkat kebutuhan, sosial budaya, pendidikan masyarakat, maupun faktor fisik dan ekologi wilayah setempat (Khomah dan Fajarningsih, 2015). Tradisi pengobatan suatu masyarakat tidak terlepas dari budaya setempat. Persepsi tentang konsep sakit, sehat, dan keranekaragaman spesies tanaman yang digunakan sebagai obat tradisional terbentuk melalui suatu proses sosialisasi yang secara turun temurun dipercaya dan diyakini kebenarannya.
Penelitian keanekaragaman dan pemanfaatan tanaman obat sangat penting dilakukan mengingat saat ini pengetahuan mengenai tanaman obat tradisional di masyarakat menjadi semakin langka (Slamet dan Andarias, 2018). Hal ini dikhawatirkan akan menghilang karena pengetahuan mengenai tumbuhan obat ini cenderung diketahui oleh kalangan pengobat tradisonal.

Penelitian tentang tanaman obat di Sulawesi Utara yang pernah dilakukan antara lain tentang pemanfaatan tanaman berkhasiat obat oleh etnis Sangihe di Kepuluan Sangihe (Pelokang et al. 2018). Pengetahuan lokal masyarakat Sulawesi Utara dalam pemanfaatan pohon hutan sebagai bahan obat tradisional (Arini 2018). Pemanfaatan tumbuhan obat di Kecamatan Bunaken, Kota Manado, Provinsi Sulawesi Utara (Lingkubi et al. 2015). Namun, penelitian tentang keanekaragaman dan pemamfaatan tanaman berkhasiat obat pada pekarangan di Dumoga Utara belum pernah dilakukan. Masalah yang muncul saat ini adalah mulai hilangnya pengetahuan mengenai pengobatan tradisional menggunakan tanaman obat akibat rendahnya minat para generasi muda terhadap pengobatan tradisional (Qamariah et al. 2018). Penelitian ini bertujuan untuk menganalisis keanekaragaman tanaman berkhasiat obat serta pemanfaatan tanaman berkhasiat obat pada pekarangan di Dumoga Utara, Kabupaten Bolaang Mongondow, Sulawesi Utara.

\section{METODE}

Penelitian ini dilaksanakan dari Bulan November sampai Desember 2020. Tempat penelitian dilaksanakan di empat lokasi yang bertempat di Kecamatan Dumoga Utara, Kabupaten Bolaang Mongondow, Sulawesi Utara. Lokasi pertama adalah pekarangan yang ditempati oleh suku Jawa di Desa Mopuya Utara, lokasi kedua suku Bali di Desa Mopugad Selatan, lokasi ketiga suku Mongondow di Desa Mopuya Selatan 1 dan lokasi keempat suku Minahasa di Desa Dondomon. 
Metode yang digunakan untuk pengambilan sampel tanaman yakni purposive sampling yaitu pengambilan sampel berdasarkan pertimbangan tertentu. Luas pekarangan yang dijadikan sampel berkisar antara $100 \mathrm{~m}^{2}-150 \mathrm{~m}^{2}$. Pada masing masing lokasi pekarangan diambil sebanyak 15 sampel pekarangan, sehingga total keseluruhan sampel adalah $15 \times 4=60$ sampel pekarangan. Identifikasi spesies tanaman yang digunakan dengan bantuan buku identifikasi tanaman obat (Kinho et al. 2011; Simbala dan Queljoe, 2015; Kementerian Pertanian, 2019; Mindarti dan Nurbaeti, 2015).

Analisis data dalam penelitian ini adalah menganalisis keanekaragaman dan mengkaji pemanfaatan secara deskriptif. Analisis keanekaragaman meliputi analisis kelimpahan spesies, indek kekayaan spesies, indek keanekaragaman dan indek kemerataan spesies tanaman obat. Kelimpahan spesies merupakan jumlah individu pada suatu spesies. Indeks kekayaan spesies yang digunakan adalah indeks kekayaanMargalef (Mangurran, 1998) dengan rumus:

$$
\mathrm{D}_{\mathrm{mg}}=\frac{(\mathrm{S}-1)}{\ln \mathrm{N}}
$$

Keterangan: $\mathrm{DMg}=$ indeks kekayaan jenis Margalef; $\mathrm{S}=$ Jumlah jenis; $\mathrm{N}=$ Total individu

Indeks keanekaragaman spesies dianalisis dengan menggunakan Indeks Keanekaragaman Shannon-Wiener dengan rumus:

$$
\mathrm{H}^{\prime}=-\sum \mathrm{Pi} \ln \mathrm{Pi}
$$

$H^{\prime}=$ Indeks keanekaragaman Shannon-Wiener; $\mathrm{Pi}=$ Proporsi jumlah individu ke-i $(\mathrm{ni} / \mathrm{N})$; ni= Kelimpahan spesies ke-I; N= Kelimpahan total spesies yang ditemukan dan $\sum=$ Jumlah (Fachrul, 2006).

Indeks kemerataan digunakan rumus:

$$
\mathrm{E}=\frac{\mathrm{H}^{\prime}}{\operatorname{Ln} S},
$$

$\mathrm{E}=$ indeks kemerataan (nilai antara 0-1), $\mathrm{H}^{\prime}$ = indeks keanekaragaman Shannon - Wiener dan $S=$ jumlah spesies (Mangurran, 1998).
Data pemanfaatan tanaman obat pekarangan diperoleh melalui wawancara dengan orang yang dianggap mengetahui tentang penggunaan tumbuhan obat yaitu pengobat tradisioal (Batra). Pemilihan responden untuk wawancara ini dilakukan dengan metode snowball sampling. Jumlah responden yang dipilih (Batra) sebanyak 3 orang dari 3 desa, rasio jenis kelamin terdiri laki-laki (1 orang) dan perempuan (2 orang).

\section{HASIL DAN PEMBAHASAN Keanekaragaman Tanaman Obat}

Hasil penelitian didapatkan tanaman obat pada pekarangan masyarakat Dumoga Utara, sebanyak 25 famili yang terdiri dari 46 spesies dan 2691 Individu tanaman obat (Tabel 1). Famili yang paling banyak ditemukan jumlah spesies dan individunya adalah Zingiberaceae (8 spesies). Jumlah spesies tanaman obat yang paling banyak ditemukan pada pekarangan Suku Jawa yaitu 40 spesies, kemudian Suku Mongondow 36 spesies. Pada pekarangan Suku Minahasa dan Bali masing masing 26 spesies dan 23 spesies. Spesies yang memiliki kelimpahan atau jumlah individu terbanyak tanaman Katu (Sauropus androgynus (L.) Merr.) sebanyak 476 individu. Spesies terbanyak berikutnya adalah tanaman Jahe (Zingiber officinale Roscoe) sebanyak 313 individu dan tanaman Kunyit (Curcuma longa L.) sebanyak 312 individu (Tabel 1).

Jumlah spesies tanaman obat pekarangan yang ditemukan dalam penelitian ini lebih banyak jika dibandingkan dengan penelitian Yowa et al. (2019) yang menemukan 19 famili dan 31 spesies tanaman obat pekarangan di Desa Umbu Langang Kabupaten Sumba Tengah. Izzuddin dan Azrianingsih (2015) menemukan tumbuhan berkhasiat obat di Kampung Adat Urug lebih banyak yaitu 53 spesies, tergolong dalam 27 famili. Perbedaan jumlah spesies tanaman obat yang ditemukan disebabkan karena kurangnya pengetahuan pemanfaatan tanaman obat, dan memungkinkan terjadinya penurunan produktivitas tanaman obat pada lahan pekarangan penduduk sekitar. 
Tabel 1. Jumlah famili, spesies dan individu tanaman obat yang ditemukan pada pekarangan yang dihuni oleh empat suku di Kecamatan Dumoga Utara

\begin{tabular}{|c|c|c|c|c|c|c|c|c|c|}
\hline \multirow{2}{*}{ No. } & \multirow{2}{*}{ Famili } & \multirow{2}{*}{ Nama Lokal } & \multirow{2}{*}{ Spesies } & \multicolumn{4}{|c|}{ Pada Pekarangan Suku } & \multirow{2}{*}{ Jumlah } & \multirow{2}{*}{ Presentase } \\
\hline & & & & Bali & Jawa & Minahasa & Mongondow & & \\
\hline 1 & Acanthaceae & Keji Beling & Strobilanthes crispus $\mathrm{Bl}$. & 0 & 37 & 0 & 5 & 42 & 1,56 \\
\hline 2 & Acanthaceae & Sambiloto & Andrographys paniculata $\mathrm{L}$. & 0 & 2 & 0 & 0 & 2 & 0,07 \\
\hline 3 & Annonaceae & Sirsak & Annona muricata $\mathrm{L}$. & 2 & 3 & 8 & 15 & 28 & 1,04 \\
\hline 4 & Annonaceae & Srikaya & Annona squamosa $\mathrm{L}$. & 0 & 1 & 0 & 4 & 5 & 0,19 \\
\hline 5 & Arecaceae & Kelapa & Coccos nucifera $\mathrm{L}$. & 39 & 23 & 23 & 31 & 116 & 4,31 \\
\hline 6 & Arecaceae & Pinang & Areca catechu $\mathrm{L}$. & 29 & 3 & 3 & 25 & 60 & 2,23 \\
\hline 7 & Asteraceae & Beluntas & Pluchea indica Iess & 0 & 0 & 0 & 87 & 87 & 3,23 \\
\hline 8 & Asteraceae & Daun Afrika & Vernonia amygdalina Del. & 0 & 20 & 0 & 0 & 20 & 0,74 \\
\hline 9 & Basellaceae & Gendola & Basella alba $\mathrm{L}$. & 0 & 3 & 0 & 0 & 3 & 0,11 \\
\hline 10 & Caricaceae & Pepaya & Carica papaya $\mathrm{L}$. & 7 & 14 & 21 & 43 & 85 & 3,16 \\
\hline 11 & Clusiaceae & Manggis & Garcinia mangostana $\mathrm{L}$. & 4 & 2 & 1 & 0 & 7 & 0,26 \\
\hline 12 & Convolulaceae & Ubi Jalar & Ipomoea batatas Poir. & 10 & 0 & 3 & 14 & 27 & 1,00 \\
\hline 13 & Crassulaceae & Cocor Bebek & Kalanchoe pinnata (Lam) & 0 & 25 & 8 & 1 & 34 & 1,26 \\
\hline 14 & Euphorbiaceae & Jarak Merah & Jatropha gossypifolia (L.) Pohl & 2 & 3 & 4 & 8 & 17 & 0,63 \\
\hline 15 & Euphorbiaceae & Jarak Putih & Jatropha curcas L. & 1 & 3 & 0 & 9 & 13 & 0,48 \\
\hline 16 & Euphorbiaceae & Katu & Sauropus androgynus (L.) Merr. & 30 & 68 & 35 & 343 & 476 & 17,69 \\
\hline 17 & Fabaceae & Turi & Sesbania grandiflora (L.) Pers. & 0 & 2 & 0 & 0 & 2 & 0,07 \\
\hline 18 & Iridaceae & Bawang hutan & Eleutherine americana Merr. & 0 & 0 & 0 & 3 & 3 & 0,11 \\
\hline 19 & Lamiaceae & Daun Tebal & Plectranthus amboinicus (Lour.) Spreng & 8 & 2 & 4 & 0 & 14 & 0,52 \\
\hline 20 & Lamiaceae & Kumis Kucing & Orthosiphon spicatus (Blume) Miq. & 1 & 1 & 0 & 9 & 11 & 0,41 \\
\hline 21 & Lamiaceae & Mayana & Coleus scutellaroides Benth. & 0 & 5 & 1 & 0 & 6 & 0,22 \\
\hline 22 & Lauraceae & Alpukat & Persea americana P. Mill. & 0 & 4 & 6 & 2 & 12 & 0,45 \\
\hline 23 & Liliaceae & Lidah Buaya & Aloe vera $\mathrm{L}$. & 33 & 23 & 10 & 27 & 93 & 3,46 \\
\hline 24 & Malvaceae & Gedi & Abelmoschus manihot $\mathrm{L}$. & 0 & 2 & 33 & 9 & 44 & 1,64 \\
\hline 25 & Malvaceae & Randu & Ceiba petandra (L.) Gaetrn. & 0 & 10 & 8 & 31 & 49 & 1,82 \\
\hline 26 & Moringaceae & Kelor & Moringa oliefera $\mathrm{L}$. & 6 & 6 & 2 & 15 & 29 & 1,08 \\
\hline 27 & Myrtaceae & Cengkeh & Syzygium aromaticum (L.) Merr \& Perry & 0 & 1 & 2 & 13 & 16 & 0,59 \\
\hline 28 & Myrtaceae & Jambu Batu & Psidium guajava $\mathrm{L}$. & 22 & 23 & 28 & 28 & 101 & 3,75 \\
\hline 29 & Pandanaceae & Pandan & Pandanus amaryllifolius Roxb. & 3 & 29 & 17 & 12 & 61 & 2,27 \\
\hline 30 & Piperaceae & Sirih & Piper betle L. & 29 & 8 & 1 & 14 & 52 & 1,93 \\
\hline 31 & Poaceae & Jagung & Zea mays $\mathrm{L}$. & 0 & 0 & 46 & 0 & 46 & 1,71 \\
\hline 32 & Poaceae & Sereh & Cymbopogon citratus $\mathrm{L}$. & 21 & 21 & 65 & 39 & 146 & 5,43 \\
\hline 33 & Poaceae & Sereh wangi & Cymbopogon nardus $\mathrm{L}$. & 0 & 3 & 0 & 14 & 17 & 0,63 \\
\hline 34 & Rosaseae & Mawar & Rosa $\mathrm{Sp}$ & 1 & 10 & 0 & 26 & 37 & 1,37 \\
\hline 35 & Rubiaceae & Mengkudu & Morinda citrifolia $\mathrm{L}$. & 3 & 5 & 0 & 0 & 8 & 0,30 \\
\hline 36 & Rutaceae & Jeruk Nipis & Citrus aurantifolia (Cristm.) Swingle & 0 & 0 & 0 & 4 & 4 & 0,15 \\
\hline 37 & Rutaceae & Jeruk Purut & Citrus hystrix DC. & 1 & 4 & 3 & 5 & 13 & 0,48 \\
\hline 38 & Tymelaeaceae & Mahkota Dewa & Phaleria macrocarpa (Scheff.) Boerl. & 0 & 0 & 0 & 1 & 1 & 0,04 \\
\hline 39 & Zingiberaceae & Jahe & Zingiber officinale Roscoe & 77 & 55 & 76 & 105 & 313 & 11,63 \\
\hline 40 & Zingiberaceae & Kencur & Kaempferia galanga $\mathrm{L}$. & 0 & 64 & 0 & 7 & 71 & 2,64 \\
\hline 41 & Zingiberaceae & Kunyit & Curcuma longa $\mathrm{L}$. & 59 & 63 & 74 & 116 & 312 & 11,59 \\
\hline 42 & Zingiberaceae & Lempuyang & Zingiber zerumbet (L.) J.E. Smith & 0 & 15 & 0 & 0 & 15 & 0,56 \\
\hline 43 & Zingiberaceae & Lengkuas & Alpinia galanga (L.) Willd. & 75 & 8 & 8 & 41 & 132 & 4,91 \\
\hline 44 & Zingiberaceae & Temu Kunci & Boesenbergia rotunda (L.) Mansf. & 0 & 15 & 0 & 1 & 16 & 0,59 \\
\hline 45 & Zingiberaceae & Temu Putih & Curcuma zedoaria (Berg.) Roscoe & 0 & 4 & 0 & 2 & 6 & 0,22 \\
\hline 46 & Zingiberaceae & Temulawak & Curcuma xanthorrhiza Robx. & 0 & 31 & 0 & 8 & 39 & 1,45 \\
\hline & & & Total & 463 & 621 & 490 & 1117 & 2691 & 100,00 \\
\hline
\end{tabular}

Tanaman obat yang banyak ditemukan pada pekarangan di Dumoga Utara adalah tanaman Katuk (Sauropus androgynus (L.) Merr.). Hal ini disebabkan karena tanaman tersebut dipercaya mampu membantu produksi ASI bagi ibu menyusui yang memiliki ASI kurang lancar atau sedikit. Hal tersebut didukung oleh hasil penelitian yang menyatakan bahwa daun katuk mengandung beberapa senyawa alifatik yang diduga mampu memberikan efek hormonal senyawa kimia sterol yang bersifat estrogenik, sehingga senyawa alifatik inilah yang memiliki khasiat untuk peningkatan produksi ASI (Elsabrina, 2013). Menurut
Margono (2013) tanaman katuk bermanfaat untuk mengobati bisul, demam dan darah kotor. Kegunaan lain dari tanaman katuk adalah daunya dikenal luas oleh masyarakat untuk pelancar ASI/laktagogum. Selain dimanfaatkan sebagai tanaman obat, tanaman ini banyak digunakan sebagai tanaman pagar yang bertujuan untuk melindungi batas pekarangannya.

Jahe (Zingiber officinale Roscoe) termasuk famili Zingiberaceae merupakan tanaman yang dominan dijumpai pada semua pekarangan. Tanaman ini banyak ditemukan karena penanaman tanaman dari famili Zingiberaceae relatif mudah ditanam 
karena menggunakan akar berupa rimpang dengan tunas yang dapat tumbuh dengan cepat. Tanaman jahe banyak ditanam dan dimanfaatkan masyarakat sebagai obat batuk dan peningkat imunitas tubuh. Menurut Bardan (2007) pemberian minuman jahe madu dapat menurunkan keparahan batuk pada anak, karena kandungan minyak atsiri dalam jahe merupakan zat aktif yang dapat mengobati batuk. Selain itu, kandungan senyawa bioaktif seperti anti inflamasi, antioksidan mampu mengobati penyakit lainnya.

Tanaman kunyit (Curcuma longa L.) merupakan tanaman yang banyak dimanfaatkan warga sebagai penurun rasa kram atau nyeri perut ketika menjelang haid. Penelitian Wulandari et al. (2018) melaporkan bahwa tanaman kunyit dapat dipercaya untuk mengatasi atau menyembuhkan dismenorea (nyeri haid). Kandungan senyawa fenolik pada kunyit dapat digunakan sebagai antioksidan, analgetika, antimikroba, anti inflamasi. Secara lebih spesifik kandungan curcumine pada kunyit dapat menghambat terjadinya reaksi Cyclooxygenase (COX) sehingga dapat menghambat dan mengurangi terjadinya inflamasi dan akan mengurangi serta menghambat kontraksi uterus yang meyebabkan nyeri haid.

Tanaman obat yang diambil merupakan jenis tanaman yang sengaja dibudidayakan pada pekarangan masyarakat. Jenis-jenis tanaman tersebut banyak ditemukan di pekarangan Dumoga Utara karena sangat mudah perawatannya. Menurut Susanti (2011) pertumbuhan dan perkembangan yang cepat dapat terjadi karena kondisi yang cukup optimal dan memiliki habitat yang sesuai. Oleh karena itu, tanaman obat yang didapatkan pada pekarangan masyarakat merupakan jenis tanaman yang mudah berkembang biak dan mampu bertahan hidup pada kondisi lingkungan sekitarnya.

Hasil analisis kelimpahan spesies didapatkan bahwa kelimpahan spesies tanaman obat tertinggi terdapat pada pekarangan yang dihuni oleh suku Mongondow, sedangkan yang terendah pada pekarangan suku Bali. Hal ini berbeda untuk indek kekayaan, indek keanekaragaman dan indek kemerataan spesies tertinggi terdapat pada pekarangan suku Jawa. Indek kemerataan terendah terdapat pada pekarangan suku Mongondow (Gambar 1).

Kelimpahan spesies merupakan banyaknya jumlah individu yang terdapat dalam suatu spesies. Kelimpahan ditentukan dari penghitungan jumlah individu tanaman obat yang ada di setiap lokasi pekarangan. Menurut Indriyanto (2006) kelimpahan adalah parameter kualitatif yang mencerminkan distribusi relatif spesies organisme dalam komunitas. Campbell et al. (2010) menyatakan bahwa kelimpahan merupakan suatu bentuk proporsi yang dipresentasikan oleh masing-masing spesies dari seluruh individu dalam komunitasnya. Perbedaan kelimpahan spesies tumbuhan pada habitat alami sangat berbeda dengan habitat pada pekarangan. Pada habitat alami kelimpahan tumbuhan sangat dipengaruhi oleh kondisi lingkungan tempat tumbuh dan juga dipengaruhi oleh kecepatan regenerasi tumbuhan (Rahasia et al. 2014).

Pada habitat buatan seperti pekarangan kelimpahan tanaman obat pada masingmasing pekarangan yang dihuni oleh berbagai suku sangat ditentukan oleh tingkat kebutuhan, sosial budaya, pendidikan masyarakat, maupun faktor fisik dan ekologi wilayah setempat (Khomah dan Fajarningsih, 2015). Najiati dan Danarti (1989) berpendapat bahwa luas lahan pekarangan juga merupakan salah satu faktor yang mempengaruhi kelimpahan spesies tanaman yang ditanam pada suatu pekarangan. Oleh karena itu, pemanfaatan lahan pekarangan penduduk menjadi salah satu aspek penting yang dapat menunjukkan nilai kelimpahan spesies tersebut.

Tanaman obat yang memiliki jumlah tanaman terbanyak merupakan jenis tanaman yang mendominasi dilahan pekarangan penduduk. Tanaman yang mendominasi memiliki nilai kerapatan yang tinggi, sebab tanaman tersebut memiliki jumlah yang paling banyak dibandingkan dengan jumlah spesies lainnya. Irwanto 
(2006) menegaskan bahwa kerapatanjenis tanaman merupakan suatu nilai yang ditunjukkan dari banyaknya jumlah suatu jenis persatuan luas, artinya semakin besar nilai kerapatan suatu jenis tanaman maka semakin banyak individu jenis tersebut.

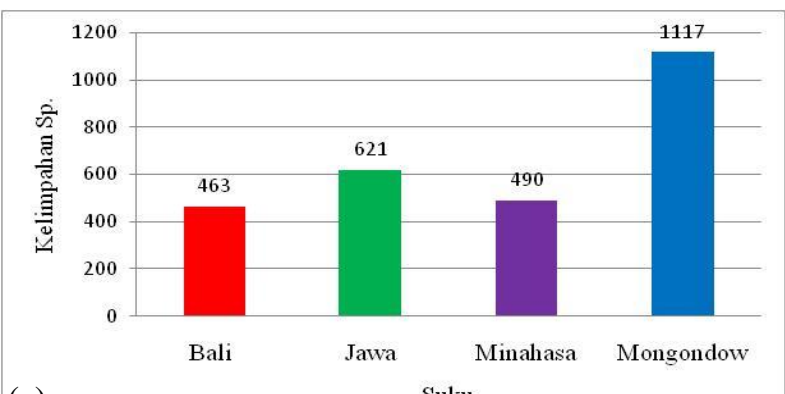

(a)

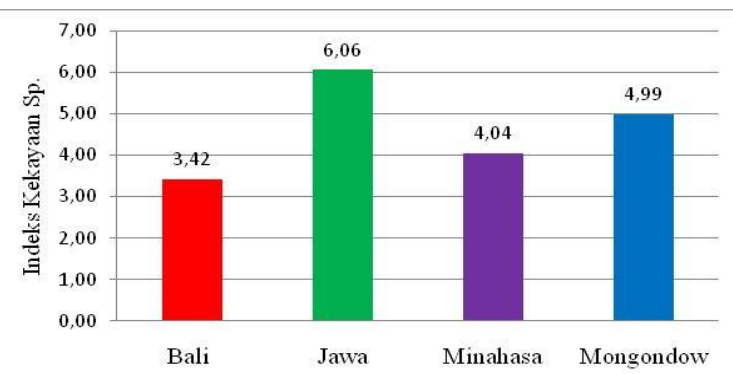

(b)
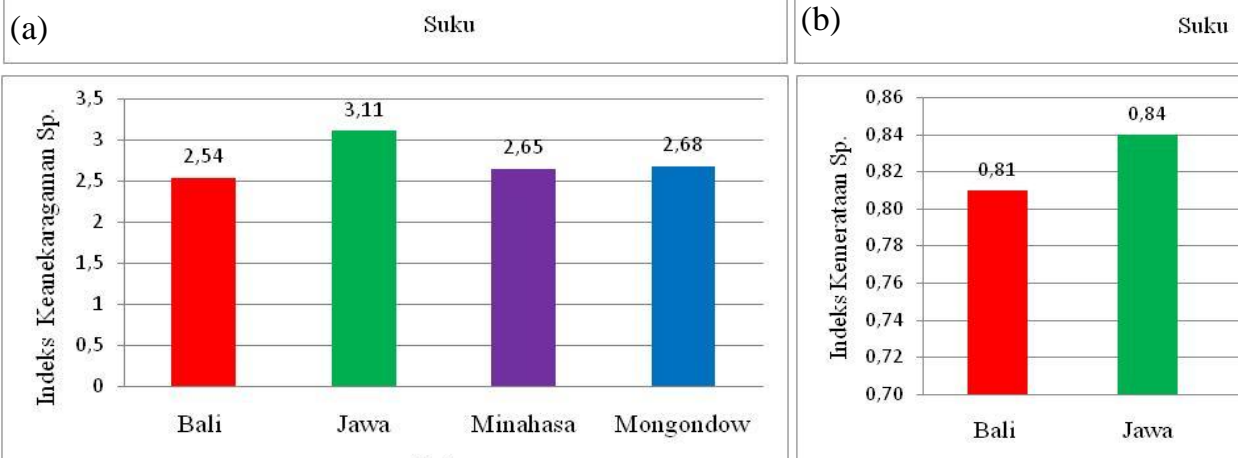

(c) Suku

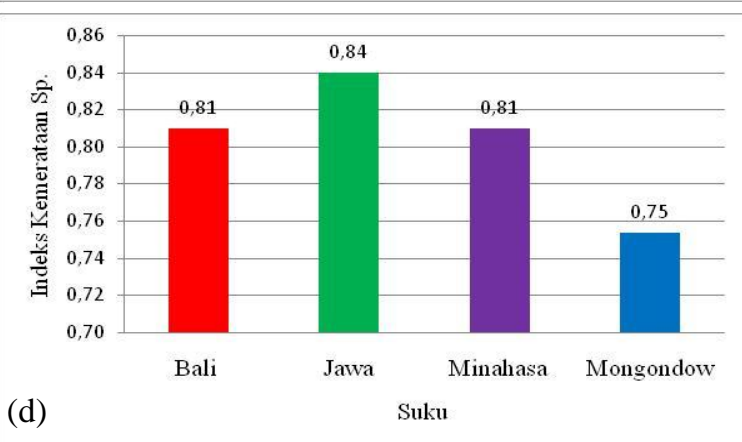

Gambar 1. Kelimpahan spesies (a), indek kekayaan spesies (b), indek keanekaragaman spesies (c) dan indek kemerataan spesies(d) tanaman obat pekarangan pada di Dumoga Utara.

Indeks kekayaan spesies menggunakan indeks Margalef jenis tanaman yang tertinggi pada setiap suku berbeda. Magurran (1988) menegaskan bahwa indek Margalef memiliki kemampuan merespon perbedaan kekayaan spesies yang baik dan kesensitifan tinggi. Nilai indek Shanon wiener yang diperoleh memiliki nilai tinggi apabila terdapat jumlah spesies yang tinggi dan jumlah individu yang tinggi pada masing-masing spesies, sedangkan apabila nilai Indek Margalef tinggi maka akan terdapat jumlah spesies yang tinggi. Sehingga kesensitifan keragaman spesies tanaman pada indeks Margalef akan diperoleh dengan bertambahnya jumlah spesies. Kekayaan spesies dapat bernilai tinggi jika disusun oleh banyaknya spesies yang menempati lahan pekarangan tersebut.

Apabila suatu wilayah hanya didominasi oleh jenis-jenis tertentu saja maka wilayah tersebut memiliki keanekaragaman jenis yang rendah. Pekarangan merupakan lingkungan buatan manusia yang didalamnya cenderung tanaman yang sengaja ditanam sesuai dengan keinginan pemiliknya. Pada umumnya pemilik pekarangan menanam tumbuhan yang bervariasi jenis maupun manfaat pada lahan pekarangannya. Oleh karena itu, pada suatu pekarangan tidak ada penguasaan oleh satu jenis tumbuhan saja. Hal inilah yang menyebabkan, nilai kekayaan spesies pada indek bergantung dari jumlah spesies tanaman yang ditemukan dalam suatu sampel pekarangan (Nahlunnisa et al. 2016).

Suku Jawa memiliki nilai keanekaragaman paling tinggi. Hal ini disebabkan karena penduduk setempat memanfaatkan lahan pekarangan untuk menanam berbagai jenis tanaman sehingga kemungkinan kecil ditemukannya tanaman yang mendominasi pada lahan pekarangan tersebut. Menurut Soegianto (1994) bahwa suatu komunitas dikatakan memiliki keanekaragaman spesies yang tinggi apabila disusun oleh banyaknya spesies dengan kelimpahan spesies yang hampir sama. 
Masyarakat yang masih memiliki kesadaran pentingnya pemanfaatan lahan pekarangansebagai sumber makanan, keindahan dan apotek hidup.

Indek keanekaragaman tanaman obat yang diperoleh dalam penelitian ini berkisar antara 2,54 sampai 3,11. Menurut Indriani (2009) jika indeks keanekaragaman Shannon-Weiner adalah $\mathrm{H}^{\prime}<1=$ keanekaragaman rendah, $\mathrm{H}^{\prime} \quad 1-3=$ keanekaragaman sedang, dan $\mathrm{H}^{\prime}>3=$ keanekaragaman tinggi. Hasil analisis data yang didapatkan, nilai Indeks Keanekaragaman $\left(\mathrm{H}^{\prime}\right)$ tanaman obat pada pekarangan suku Jawa memiliki nilai keanekaragaman $\left(\mathrm{H}^{\prime}>3\right)$ sebesar 3,11 yang dikategorikan dalam keanekaragaman tertinggi. Indek keanekaragaman pada pekarangan suku Bali $\left(\mathrm{H}^{\prime}=2,54\right)$, Minahasa $\left(\mathrm{H}^{\prime}=2,65\right)$ dan Mongondow $\left(\mathrm{H}^{\prime}=2,68\right)$ termasuk dalam kategori sedang $\left(\mathrm{H}^{\prime}\right.$ 1-3) (Gambar 1).

Indek kemerataan spesies (E) tanaman pada pekarangan di Kecamatan Dumoga Utara berkisar antara 0,75 samapi 0,84 . Rendahnya indek kemerataan tanaman obat pada pekarangan suku Monggondow karena adanya tanaman yang memilki kelimpahan sangat tinggi yaitu tanaman Sauropus androgynus. Dominasi tanaman pada suatu habitat akan menyebabkan indek keanekaragaman dan indek kemerataan menjadi rendah. Nilai indek kemerataan digunakan untuk mengukur derajat kemerataan kelimpahan individu spesies dalam komunitas. Kemerataan menggambarkan keseimbangan antara satu komunitas dengan komunitas lainnya. Menurut Magurran (1988) jika indek kemerataan mendekati satu menunjukkan bahwa semakin merata penyebaran dalam komunitasnya, sebaliknya jika nilai kemerataan mendekati nol maka menunjukkan semakin tidak rata penyebarannya.

\section{Pemanfaatan Tanaman Obat}

Berdasarkan hasil wawancara dan penelitian pada empat lokasi penelitian yaitu
Desa Mopuya Utara, Desa Mopuya Selatan 1, Desa Mopugad Selatan dan Desa Dondomon didapatkan 46 spesies tanaman pekarangan yang digunakan untuk mengobati 18 jenis penyakit (Tabel 2).Tanaman yang banyak dimanfaatkan masyarakat adalah spesies tanaman yang diketahui memiliki khasiat untuk menyembuhkan penyakit dan sengaja dibudidayakan di pekarangan. Selain sebagai tanaman obat, juga berperan dalam pemenuhan kebutuhan pangan penduduk dan manfaat bagi lingkungan sekitar. Hasil penelitian ini didapatkan lebih sedikit jumlah spesies tanaman obatnya jika dibandingkan dengan penelitian Haryono (2014) yang melaporkan terdapat 60 spesies tumbuhan obat yang yang digunakan untuk mengobati 49 jenis penyakit. Pada penelitian Indra (2014) menemukan 73 spesies tumbuhan obat digunakan untuk mengobati penyakit di desa Sempadian Kabupaten Sambas. Perbedaan ini disebabkan pengetahuan pengobat tradisonal (Batra) tentang pemanfaatan tanaman obat berbedabeda antar daerah dan suku.

\section{Bentuk Hidup Tanaman Obat}

Bentuk hidup tanaman (habitus) obat yang ditemukan pada pekarangan di Dumoga Utara adalah jenis tanaman herba, perdu, semak dan pohon. Bentuk hidup tanaman yang paling banyak digunakan adalah herba sebanyak 15 spesies (Gambar 2).

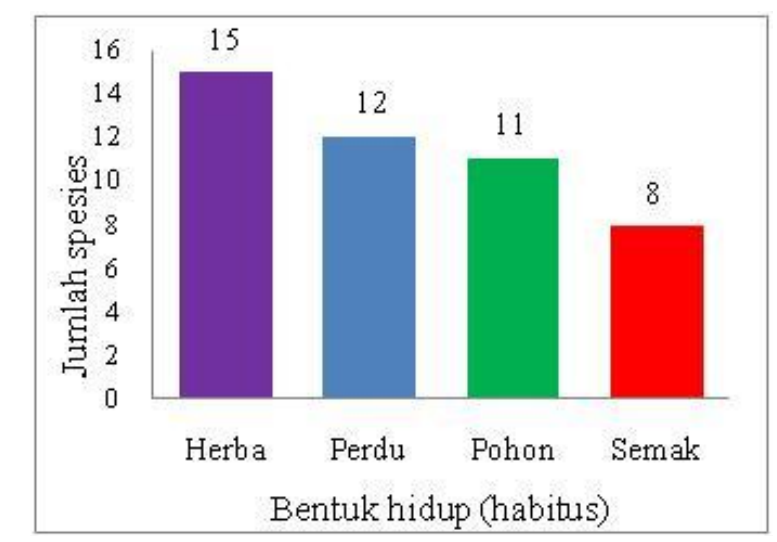

Gambar 2. Jumlah spesies tanaman obat berdasarkan bentuk hidup. 
Tabel 2. Pemanfaatan, Pengolahan, Penggunaan dan Dosis Tanaman Obat yang Digunakan pada Pekarangan di Kecamatan Dumoga Utara

\begin{tabular}{|c|c|c|c|c|c|c|c|c|}
\hline No. & Famili & Nama Lokal & Spesies & $\begin{array}{l}\text { Bentuk } \\
\text { Hidup }\end{array}$ & $\begin{array}{l}\text { Bagian } \\
\text { Yang } \\
\text { Digunakan } \\
\end{array}$ & Manfaat/Khasiat & $\begin{array}{l}\text { Cara } \\
\text { Penggunaan }\end{array}$ & Dosis \\
\hline 1 & Laueaceae & Alpukat & Persea americana P. Mill. & Pohon & Daun & $\begin{array}{l}\text { Menurunkan Tekanan } \\
\text { Darah Tinggi }\end{array}$ & Direbus & Dua Kali Sehari \\
\hline 2 & Iridaceae & Bawang hutan & Eleutherine americana Merr. & Herba & Umbi & Kanker Payudara & Ditumbuk & Sampai Sembuh \\
\hline 3 & Asteraceae & Beluntas & Pluchea indica $\mathrm{L}$. & Perdu & Daun & $\begin{array}{l}\text { Mengurangi Bau Badan } \\
\text { dan Keputihan, Nyeri } \\
\text { Rematik }\end{array}$ & Direbus & Seminggu Dua Kali \\
\hline 4 & Myrtaceae & Cengkeh & $\begin{array}{l}\text { Syzygium aromaticum }(\text { L.) Merr } \\
\& \text { Perry }\end{array}$ & Pohon & Bunga & Sakit gigi & $\begin{array}{l}\text { Tanpa } \\
\text { Pengolahan }\end{array}$ & Sampai Sembuh \\
\hline 5 & Crassulaceae & Cocor Bebek & Kalanchoe pinnata (Lam) & Semak & Daun & $\begin{array}{l}\text { Menurukan Panas Pada } \\
\text { Anak, Menyuburkan } \\
\text { Rambut }\end{array}$ & Ditumbuk & Sampai Sembuh \\
\hline 6 & Asteraceae & Daun Afrika & Vernonia amygdalina Del. & Pohon & Daun & $\begin{array}{l}\text { Segala Penyakit } \\
\text { (Kolestrol, Darah Tinggi, } \\
\text { Diabetes) }\end{array}$ & Direbus & Dua Kali Sehari \\
\hline 7 & Lamiaceae & Daun Tebal & $\begin{array}{l}\text { Plectranthus amboinicus (Lour.) } \\
\text { Spreng }\end{array}$ & Semak & Daun & Demam & Ditumbuk & Sampai Sembuh \\
\hline 8 & Malvaceae & Gedi & Abelmoschus manihot $\mathrm{L}$. & Semak & Daun & Membantu Pencernaan & Direbus & Sering \\
\hline 9 & Basellaceae & Gendola & Basella alba $\mathrm{L}$. & Herba & Akar, Daun & $\begin{array}{l}\text { Pegal Linu, Sembelit, } \\
\text { Strok }\end{array}$ & Direbus & $\begin{array}{l}\text { Sehari Sekali, Sampai } \\
\text { Sembuh }\end{array}$ \\
\hline 10 & Poaceae & Jagung & Zea mays $\mathrm{L}$. & Perdu & Buah & Cacar & Ditumbuk & Sampai Sembuh \\
\hline 11 & Zingiberaceae & Jahe & Zingiber officinale Roscoe & Herba & Rimpang & $\begin{array}{l}\text { Batuk, Meningkatkan } \\
\text { Imunitas }\end{array}$ & Direbus & Dua Kali Sehari \\
\hline 12 & Myrtaceae & Jambu Batu & Psidium guajava $\mathrm{L}$. & Perdu & Daun & Mencret & $\begin{array}{l}\text { Tanpa } \\
\text { Pengolahan }\end{array}$ & Sampai Sembuh \\
\hline 13 & Euphorbiaceae & Jarak Merah & Jatropha gossypifolia (L.) Pohl & Perdu & Daun & $\begin{array}{l}\text { Obat Mencret Pada Anak- } \\
\text { anak, Ambeyen }\end{array}$ & Ditumbuk & Tiga Kali Sehari \\
\hline 14 & Euphorbiaceae & Jarak Putih & Jatropha curcas L. & Perdu & Daun & $\begin{array}{l}\text { Obat Kembung Pada } \\
\text { Anak-anak }\end{array}$ & Ditumbuk & Sampai Sembuh \\
\hline 15 & Rutaceae & Jeruk Nipis & $\begin{array}{l}\text { Citrus aurantifolia (Cristm.) } \\
\text { Swingle }\end{array}$ & Perdu & Buah & Batuk, Jerawat & Diperas & $\begin{array}{l}\text { Tiga Kali Sehari, } \\
\text { Sampai Sembuh }\end{array}$ \\
\hline 16 & Rutaceae & Jeruk Purut & Citrus hystrix DC. & Perdu & Daun, Buah & $\begin{array}{l}\text { Meningkatkan Imunitas, } \\
\text { Obat Kuat }\end{array}$ & Direbus & Seminggu Sekali \\
\hline 17 & Euphorbiaceae & Katu & Sauropus androgynus (L.) Merr. & Perdu & Daun & Memperlancar ASI & Direbus & Sering \\
\hline 18 & Acanthaceae & Keji Beling & Strobilanthes crispus B1. & Semak & Daun & $\begin{array}{l}\text { Kencing Batu, Kencing } \\
\text { Kurang Lancar }\end{array}$ & Direbus & Tiga Kali Sehari \\
\hline 19 & Arecaceae & Kelapa & Coccos nucifera $\mathrm{L}$. & Pohon & Buah & Penawar Racun & $\begin{array}{l}\text { Tanpa } \\
\text { Pengolahan }\end{array}$ & Sampai Sembuh \\
\hline 20 & Moringaceae & Kelor & Moringa oliefera $\mathrm{L}$. & Pohon & Akar, Daun & $\begin{array}{l}\text { Nyeri dan Pegal Linu, } \\
\text { Biduran }\end{array}$ & Direbus & Dua Kali Sehari \\
\hline 21 & Zingiberaceae & Kencur & Kaempferia galanga $\mathrm{L}$. & Semak & Rimpang & $\begin{array}{l}\text { Memperlancar ASI, } \\
\text { Memperlancar Peredaran } \\
\text { Darah }\end{array}$ & $\begin{array}{l}\text { Ditumbuk, } \\
\text { Direbus }\end{array}$ & Dua Kali Sehari \\
\hline 22 & Lamiaceae & Kumis Kucing & $\begin{array}{l}\text { Orthosiphon spicatus (Blume) } \\
\text { Miq. }\end{array}$ & Herba & Daun & $\begin{array}{l}\text { Kencing Batu, Infeksi } \\
\text { Saluran Kencing }\end{array}$ & Direbus & Tiga Kali Sehari \\
\hline 23 & Zingiberaceae & Kunyit & Curcuma longa $\mathrm{L}$. & Herba & Rimpang & $\begin{array}{l}\text { Melancarkan Peredaran } \\
\text { Darah, Mengurangi Rasa } \\
\text { Nyeri Haid, } \\
\text { Meningkatkan Imunitas }\end{array}$ & $\begin{array}{l}\text { Ditumbuk, } \\
\text { Direbus }\end{array}$ & Tiga Kali Sehari \\
\hline 24 & Zingiberaceae & Lempuyang & Zingiber zerumbet (L.) J.E. Smith & Semak & Rimpang & $\begin{array}{l}\text { Menghangatkan Tubuh, } \\
\text { Menjaga Daya Tahan } \\
\text { Tubuh }\end{array}$ & $\begin{array}{l}\text { Ditumbuk, } \\
\text { Direbus }\end{array}$ & Dua Kali Sehari \\
\hline 25 & Zingiberaceae & Lengkuas & Alpinia galanga $(\mathrm{L}$.$) Willd.$ & Herba & Rimpang & $\begin{array}{l}\text { Panu, Meningkatkan } \\
\text { stamina }\end{array}$ & $\begin{array}{l}\text { Digosok, } \\
\text { Ditumbuk, } \\
\text { Direbus }\end{array}$ & Dua Kali Sehari \\
\hline 26 & Liliaceae & Lidah Buaya & Aloe vera $\mathrm{L}$. & Herba & Daun & $\begin{array}{l}\text { Menumbuhkan Rambut, } \\
\text { Luka Bakar }\end{array}$ & Digosok & Sampai Sembuh \\
\hline 27 & Tymelaeaceae & Mahkota Dewa & $\begin{array}{l}\text { Phaleria macrocarpa (Scheff.) } \\
\text { Boerl. }\end{array}$ & Perdu & Buah & Hipertensi & Direbus & Rutin, Sehari Sekali \\
\hline 28 & Clusiaceae & Manggis & Garcinia mangostana $\mathrm{L}$. & Pohon & Kulit Buah & Penambah Darah & Direbus & Dua kali sehari \\
\hline 29 & Rosaseae & Mawar & Rosa Sp. & Perdu & Bunga & $\begin{array}{l}\text { Meredakan Rasa Sakit } \\
\text { Ketika Disengat } \\
\text { Tawon/Lebah }\end{array}$ & Digosok & $\begin{array}{l}\text { Sampai Berkurang } \\
\text { Rasa Sakit }\end{array}$ \\
\hline 30 & Lamiaceae & Mayana & Coleus scutellaroides Benth. & Herba & Daun & Batuk Berdahak & Ditumbuk & Tiga Kali Sehari \\
\hline 31 & Rubiaceae & Mengkudu & Morinda citrifolia $\mathrm{L}$. & Pohon & Buah & Batuk & $\begin{array}{l}\text { Tanpa } \\
\text { Pengolahan }\end{array}$ & Tiga Kali Sehari \\
\hline 32 & Pandanaceae & Pandan & Pandanus amaryllifolius Roxb. & Semak & Daun & $\begin{array}{l}\text { Menurunkan Tekanan } \\
\text { Darah Tinggi }\end{array}$ & Direbus & Rutin, Sehari Sekali \\
\hline 33 & Caricaceae & Pepaya & Carica papaya $\mathrm{L}$. & Perdu & Herba & Malaria & Direbus & Sehari Sekali \\
\hline 34 & Arecaceae & Pinang & Areca catechu $\mathrm{L}$. & Pohon & Biji & Menguatkan Gigi & $\begin{array}{l}\text { Tanpa } \\
\text { Pengolahan }\end{array}$ & Sering \\
\hline 35 & Malvaceae & Randu & Ceiba petandra (L.) Gaetrn. & Pohon & Daun & $\begin{array}{l}\text { Melancarkan Proses } \\
\text { Lahiran }\end{array}$ & Diperas & Seminggu Dua Kali \\
\hline
\end{tabular}




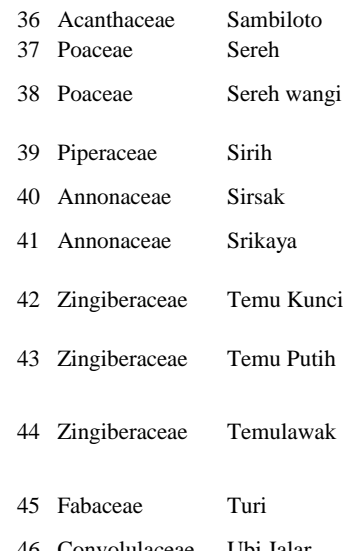

Tjitrosoepomo

(1993)

Andrographys paniculata $\mathrm{L}$.

Cymbopogon citratus L. Herba

Cymbopogon nardus $\mathrm{L}$.

Piper betle $\mathrm{L}$

Annona muricata L.

Annona squamosa $\mathrm{L}$.

Boesenbergia rotunda (L.)

Mansf.

Curcuma zedoaria (Berg.) Roscoe Semak

Curcuma xanthorrhiza Robx. Herba

Sesbania grandiflora (L.) Pers. Pohon

Ipomoea batatas Poir.

Herba

\begin{tabular}{|c|c|c|c|}
\hline Daun & Darah Tinggi, Demam & Direbus & Tiga Kali Sehari \\
\hline Batang & Meningkatkan Imunitas & Direbus & Tiga Kali Sehari \\
\hline Batang & $\begin{array}{l}\text { Patah Tulang, Mengatasi } \\
\text { Bau Mulut }\end{array}$ & $\begin{array}{l}\text { Ditumbuk, } \\
\text { Direbus }\end{array}$ & Sampai Sembuh \\
\hline Daun & $\begin{array}{l}\text { Mimisan, Menguatkan } \\
\text { Gigi, Koreng, Jerawat }\end{array}$ & $\begin{array}{l}\text { Ditumbuk, } \\
\text { Direbus, }\end{array}$ & Sering \\
\hline Daun & Kolestrol & Direbus & Sehari Sekali \\
\hline Daun & $\begin{array}{l}\text { Meningkatkan Nafsu } \\
\text { Makan Anak }\end{array}$ & $\begin{array}{l}\text { Tanpa } \\
\text { Pengolahan }\end{array}$ & Sering \\
\hline Rimpang & Sakit Pinggang & Direbus & Dua Kali Sehari \\
\hline Rimpang & Kista Rahim, Nyeri Haid & Ditumbuk & Dua Kali Sehari \\
\hline Rimpang & $\begin{array}{l}\text { Meningkatkan Nafsu } \\
\text { Makan, Meningkatkan } \\
\text { Imunitas }\end{array}$ & $\begin{array}{l}\text { Ditumbuk, } \\
\text { Direbus }\end{array}$ & Dua Kali Sehari \\
\hline Daun & Batuk, Demam & Ditumbuk & Dua Kali Sehari \\
\hline Daun & Bisul & Ditumbuk & Sampai Sembuh \\
\hline
\end{tabular}

kandungan air yang tinggi, selain itu daun merupakan tempat akumulasi fotosintesis yang mengandung unsur-unsur zat organik. Menurut Handayani (2003), daun lebih banyak digunakan dalam pengobatan tradisional karena daun memiliki tekstur yang lunak, kandungan air tinggi, sebagai tempat akumulasi fotosintat yang mengandung unsur-unsur zat organik untuk menyembuhkan penyakit. Menurut Yowa et al. (2019) melaporkan bahwa daun merupakan bagian organ tanaman yang banyak dipakai dalam meramu tumbuhan obat adalah daun. Menurut Zuhud dan Hidayat (2009) bahwa daun merupakan bagian tanaman yang paling banyak digunakan sebagai obat dengan kuantitas sebanyak 749 jenis $(33,50 \%)$ dari total tumbuhan obat hutan tropis Indonesia.

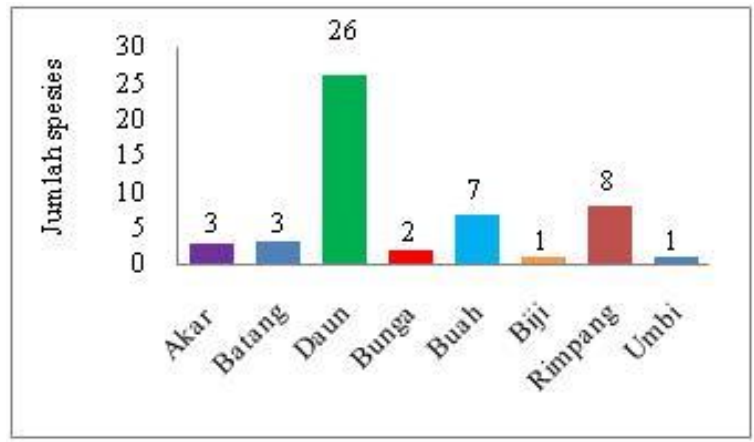

Gambar 3. Bagian tanaman yang dimanfaatkan sebagai obat

Proses pengolahan tanaman obat didapatkan 4 proses diantaranya yaitu direbus, ditumbuk, diperas, digosok dan tanpa pengolahan. Pengolahan yang paling banyak dilakukan yaitu dengan cara direbus tanaman. Daun juga memiliki tekstur umumnya lunak sebab mempunyai 
sebanyak 26 spesies tanaman obat (Gambar 4). Hal ini disebabkan pengolahan tanaman obat dalam bentuk ramuan dan dengan cara direbus merupakan cara pengolahan yang paling mudah dilakukan dibanding dengan cara yang lain. Beberapa penelitian melaporkan bahwa bentuk pengolahan tanaman obat yang banyak dilakukan adalah dengan proses direbus. Proses merebus tanaman obat akan dapat melarutkan semua zat berkhasiat yang terkandung pada tanaman obat ke dalam air rebusan tersebut (Yowa et al., 2019; Lingkubi et al., 2018; Efermila et al., 2015).

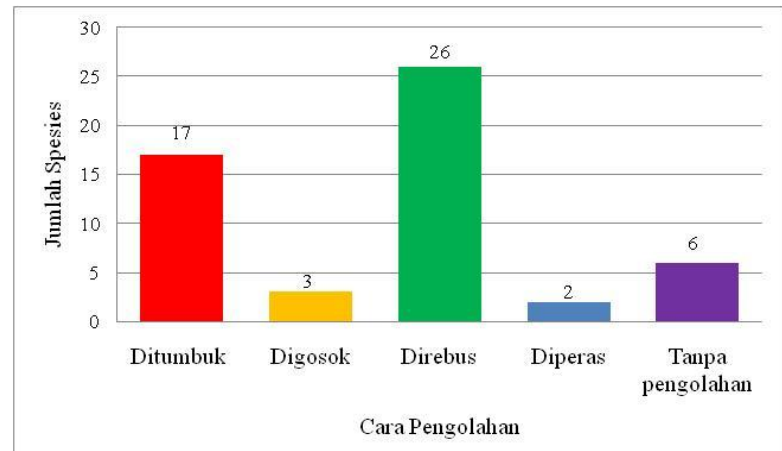

Gambar 4. Proses pengolahan tanaman sebagai obat berdasarkan jumlah spesies.

Jenis penyakit yang dapat diobati dengan tanaman obat berdasarkan hasil penelitian sebanyak 18 macam penyakit. Spesies tanaman obat yang paling banyak digunakan untuk mengobati penyakit darah tinggi, penyakit kulit, batuk dan gejala panas (Gambar 5).

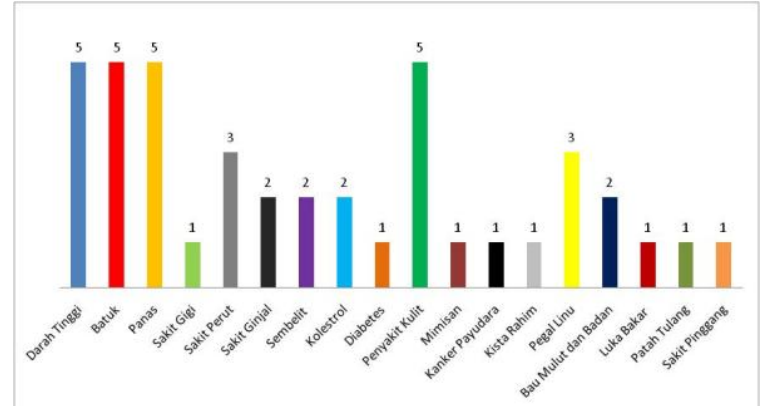

Gambar 5. Jenis penyakit berdasarkan jumlah spesies tanaman obat.

Penelitian Pelokang et al. (2018) melaporkan bahwa sebanyak 22 jenis penyakit yang digolongkan ke dalam empat jenis penyakit yaitu penyakit kronik, penyakit menular, penyakit tidak menular dan perawatan kesehatan dapat diobati dengan tumbuhan obat. Hasil penelitian diperoleh jenis penyakit yang banyak dialami masyarakat merupakan jenis penyakit yang tergolong tidak menular seperti panas, pegal linu, diare. Adapula jenis penyakit seperti sakit ginjal, kolesterol, darah tinggi, kista dan kanker digolongkan dalam penyakit kronik. Masalah bau badan, bau mulut, keputihan, serta cara meningkatkan stamina tubuh digolongkan dalam pemeliharaan kesehatan. Pengobatan dengan tanaman obat yang dilakukan dikategorikan menjadi dua macam, yaitu pengobatan penyakit luar dan pengobatan untuk penyakit dalam.

Tanaman daun afrika merupakan tanaman yang banyak dimanfaatkan oleh masyarakat sekitar, sebab tanaman tersebut dianggap mampu mengatasi beberapa penyakit sekaligus seperti darah tinggi, kolesterol dan diabetes. Tanaman Katuk banyak dimanfaatkan masyarakat sebagai pelancar ASI serta sebagai sayur mayur. Selain itu, tanaman daun tebal merupakan jenis tanaman yang sering digunakan untuk mengobati panas pada bayi. Oleh karena itu, jenis tanaman tersebut banyak dijumpai pada pekarangan suku di Dumoga Utara.

\section{KESIMPULAN}

Tanaman obat yang ditemukan pada pekarangan di Dumoga Utara sebanyak 26 famili yang terdiri dari 46 spesies dan 2691 individu. Zingiberaceae merupakan famili tanaman obat yang paling banyak ditemukan jumlah spesies dan individunya, sedangkan spesies yang dominan ditemukan adalah Zingiber officinale. Kelimpahan spesies tanaman obat tertinggi ditemukan pada pekarangan Suku Mongondow, sedangkan indek kekayaan, indek keanekaragaman dan indek kemerataan spesies tanaman obat tertinggi terdapat pada pekarangan Suku Jawa. Spesies tanaman obat pekarangan yang ditemukan dapat dimanfaatkan untuk mengobati 18 jenis penyakit. Herba 
merupakan bentuk hidup tanaman yang banyak dimanfaatkan untuk pengobatan penyakit. Bagian organ tanaman yang sering diambil untuk dimanfaatkan untuk pengobatan adalah daun. Proses pengolahan tanaman obat yang dilakukan umumnya dengan cara direbus. Spesies tanaman yang banyak digunakan adalah untuk mengobati penyakit darah tinggi, penyakit kulit, batuk dan panas.

\section{DAFTAR PUSTAKA}

Arini DID (2018) Pengetahuan lokal Masyarakat Sulawesi Utara dalam pemanfaatan pohon hutan sebagai bahan obat tradisional. Jurnal Masyarakat dan Budaya. 19: 161-174.

Bardan SN (2007) Tanaman Berkhasiat Obat. PT Sunda Kelapa Pustaka, Jakarta.

Bown D (1995) The Royal Horticultural Society encyclopedia of herbs \& their uses. Dorling Kindersley Limited, London.

Campbell N., Reece A, Jane B (2010) Biologi Edisi Kedelapan, Jilid 3 (Terjemahan Oleh Damaring Tyas Wulandari). Erlangga, Jakarta.

Efremila E, Wardenaar L, Sisillia L (2015) Studi Etnobotani Tumbuhan Obat Oleh Etnis Suku Dayak di Desa Kayu Tanam Kecamatan Mandor Kabupaten Landak. Jurnal Hutan Lestari. 3:234-246.

Elsabrina (2013) Dahsyatnya Daun Obat Sepanjang Masa. Cemerlang Publishing, Yogyakarta.

Fachrul M (2006) Metode Sampling Bioekologi. Bumi Aksara, Jakarta.

Falah F, Sayaktiningsih T, Noorcahyati (2013) Keanekaragaman Jenis dan Pemanfaatan Tumbuhan Berkhasiat Obat oleh Masyarakat Sekitar Hutan Lindung Gunung Beratus Kalimantan Timur. Jurnal Penelitian dan Konservasi Alam.10: 1-18.

Handayani (2003) Membedah Rahasia Ramuan Madura. Agromedia Pustaka, Jakarta.

Haryono D (2014) Kajian Etnobotani Tumbuhan Obat di desa Menkian Kecamatan Sanggau Kapuas Kabupaten
Sanggau [Skripsi] Fakultas Kehutanan, Universitas Tanjungpura, Pontianak.

Indra (2014) Kajian Etnobotani Tanaman Obat Yang Dimanfaatkan di Desa Sempadian Kabupaten Sambas. [Skripsi]. Fakultas Kehutanan, Universitas Tanjungpura, Pontianak.

Indriani PD, Hanifa M, Zakaria (2009)

Keanekaragaman spesies tumbuhan pada kawasan mangrove nipah (Nypa fructicans wurmb.) di kec. Pulau rimau kab. Banyuasin sumatera selatan. Jurnal Penelitian Sains. 12: 1-4.

Indriyanto (2006) Ekologi Hutan. PT Bumi Aksara, Jakarta.

Izzuddin MQ, Azrianingsih R (2015) Inventarisasi Tumbuhan Obat Di Kampung Adat Urug,Desa Urug, Kecamatan Sukajaya, Kabupaten Bogor. NATURAL B. 1: 83-92.

Kementrian Pertanian (2019) Tanaman Obat. Badan Penelitian Tanaman Rempah Dan Obat.

Kinho J, Arini DID, Tabba S, Kama H, Kafiar Y, Shabri S, Karundeng MC (2011) Tumbuhan Obat Tradidional di Sulawesi Utara Jilid I. Balai Penelitian Kehutanan Manado Badan Penelitian dan Pengembangan Kehutanan Kementrian Kehutanan, Manado.

Khomah I, Fajarningsih RU (2015) Potensi dan Prospek Pemanfaatan Lahan Pekarangan terhadap Pendapatan Rumah Tangga. Proceeding Seminar Nasional Peningkatan Kapabilitas UMKM dalam Mewujudkan UMKM Naik Kelas.

Larassati A, Marmaini, Trimin K (2019) Inventarisasi Tumbuhan Berkhasiat Obat Di Sekitar Pekarangan Di Kelurahan Sentosa. Jurnal Indobiosains. 1: 76-89.

Lingkubi JR, Sumakud MY, Nurmawan W, Pangemanan EF (2015) Pemanfaatan Tumbuhan Obat di Kecamatan Bunaken, Kota Manado, Provinsi Sulawesi Utara. In Cocos, 6: 1-9.

Lubis AM, Siti Latifahb, Yunus Afifuddin (2015) Inventarisasi Tumbuhan Obat di Hutan Lindung Kec. Ulu Pungkut, Kab. Mandailing Natal. NATURAL B. 3. 
Magurran AE (1988) Ecological Diversity and Its Measurement. New Jersey (US): Princeton University Press.

Magurran AE (1998) Ecologycal Diversity and Its Measurement. New Jersey, Pricenton University Press.

Margono FEP (2013) Uji Efek Daun Katuk (Sauropusandrogynus (L.) Merr) Terhadap Kualitas Spermatozoa Tikus Putih Jantan (Rattus norwegians) Secara Histologi. Calyptra. 2: 1-14.

Mindari S, Nurbaeti B (2015) Buku Saku Tanaman Obat Keluarga (TOGA). Balai Penelitian Dan Pengembangan Pertanian.

Nahlunnnisa H, Zuhud EAM, Santosa Y (2016) Keanekaragaman Spesies Tumbuhan Di Arealnilai Konservasi Tinggi (Nkt) Perkebunan Kelapa Sawit Provinsi Riau. Media Konservasi. 21: 91-98.

Najiyati S, Danarti (1989) Kopi Budidaya dan Penanganan Lepas Panen. Penebar Swadaya, Jakarta.

Oktaviani AD, Ulayyah NNP, Yuliani TS, Rahayu MS, Lubis I, Nurul F (2020) Pemanfaatan Lahan Pekarangan untuk Memenuhi Kebutuhan Keluarga di Desa Cintalaksana, Kecamatan Tegalwaru, Kabupaten Karawang. Jurnal Pusat Inovasi Masyarakat. 2: 535-539.

Pelokang CY, Koneri R, Katili D (2018) Pemanfaatan Tumbuhan Obat Tradisional oleh Etnis Sangihe di Kepulauan Sangihe Bagian Selatan, Sulawesi Utara. Jurnal Bioslogos. 8: 4551.

Qamariah N, Mulyani E, Dewi N (2018) Inventarisasi Tumbuhan Obat Di Desa Pelangsian Kecamatan Mentawa Baru Ketapang Kabupaten Kotawaringin Timur. Borneo Journal of Pharmacy. 1: 1-10.

Rahasia RF, Tasirin JS, Langi MA, Sumarto $S$ (2014) Potensi Tumbuhan Pakan Alami bagi Monyet Hitam Sulawesi
(Macaca nigra) di Hutan Lindung Gunung Masarang. Cocos eJournal. 4: 1-4.

Rubiah, Djufri, Muhibbuddin (2015) Kajian etnobotani tumbuhan obat penyakit kulit pada masyarakat Kabupaten Pidie. Jurnal Biologi Edukasi Edisi 14. 7: 3441.

Simbala, HEI, Queljoe, ED (2015) Biodivervitas Tanaman Obat Di Sulawesi Utara. CV. Patra Media Grafindo, Bandung.

Slamet A, Andarias SA (2018) Studi Etnobotani dan Identifikasi Tumbuhan Berkhasiat Obat Masyarakat Sub Etnis Wolio Kota Baubau Sulawesi Tenggara. Proceeding Biology Education Conference. 15: 721-732.

Soegianto A (1994) Analisis kuantitatif: metode analisis populasi \& komunitas. Usaha Nasional, Surabaya.

Susanti D (2011) Komposisi dan Struktur Vegetasi di Kawasan Hutan Desa Engkersik Kecamatan Sekadau Hilir Kabupaten Sekadau. [Skripsi]. Fakultas Matematika dan Ilmu Pengetahuan Alam Universitas Tanjung pura, Pontianak.

Tjitrosoepomo G (1993) Taksonomi Tumbuhan (Dasar-Dasar Taksonomi Tumbuhan). Ed Ke-1. Gadjah Mada University Press, Yogyakarta.

Wulandari A, Rodiyani, Sari RDP (2018) Pengaruh Pemberian Ekstrak Kunyit (Curcuma longa linn) dalam Mengatasi Dismenorea. Majority. 7: 193-197.

Yowa MK, Boro TL, Danong MT (2019) Inventarisasi Jenis-Jenis Tumbuhan Berkhasiat Obat Tradisional Di Desa UmbuLangang Kecamatan Umbu Ratu Nggay Barat Kabupaten Sumba Tengah. Jurnal Biotropikal Sains. 16: 1 - 13.

Zuhud EA, Hidayat M (2009) Potensi Hutan Tropika Indonesia sebagai penyangga bahan obat alam untuk kesehatan bangsa. Jakarta. 